Revue d'études américaines. American Studies Journal

$2 \mid 2017$

(Hi)stories of American Women: Writings and Rewritings / Call and Answer: Dialoguing the American West in France

\title{
A Day in the Life of the American Woman: Construction and Mediation of the "American Woman" in Photographic Essays
}

Jane Bayly

\section{(2) OpenEdition}

\section{Journals}

Electronic version

URL: https://journals.openedition.org/transatlantica/9910

DOI: 10.4000/transatlantica.9910

ISSN: $1765-2766$

\section{Publisher}

Association française d'Etudes Américaines (AFEA)

\section{Electronic reference}

Jane Bayly, "A Day in the Life of the American Woman: Construction and Mediation of the "American Woman" in Photographic Essays", Transatlantica [Online], 2 | 2017, Online since 18 May 2019, connection on 01 February 2023. URL: http://journals.openedition.org/transatlantica/9910 ; DOI: https://doi.org/10.4000/transatlantica.9910

This text was automatically generated on 1 February 2023.

\section{c)}

Creative Commons - Attribution-NonCommercial-NoDerivatives 4.0 International - CC BY-NC-ND 4.0 https://creativecommons.org/licenses/by-nc-nd/4.0/ 


\title{
A Day in the Life of the American Woman: Construction and Mediation of the "American Woman" in Photographic Essays
}

\author{
Jane Bayly
}

\section{Introduction}

1 As indicated by the title of Life magazine's 1945 article "What is the American Look," defining the "American woman," has long been featured in the pages of the American mass media ("What is the American Look" 87). Again the December 24, 1956 issue of Life focused on "The American Woman." The cover photograph shows a young, white, middle-class mother and her daughter smiling affectionately at each other while touching foreheads. Inside this special issue the readers discovered more photographs of the American woman as a wife, a mother, a homemaker, mirroring the image of the traditional family that flourished in the newsmagazines and advertisements in the 1950s era. ${ }^{1}$ Defining the American woman continues to be a preoccupation today, as can be seen with the publication of magazine articles in the same vein such as an October 26, 2009 Time "special report" entitled "The State of the American Woman."

2 In addition to ephemeral magazine articles, another media format relying heavily on photographs-the photo-book-also attempts to define the American woman today. A lot of photo-books, such as Girl Culture by Lauren Greenfield (2002) and Regarding Emma: Photographs of American Women and Girls by Melissa Ann Pinney and Ann Patchet (2003), are monographs by women documentary photographers who focus on feminine identity and the experience of girlhood. In the words of Pinney, "these photographs bear witness to the speed at which little girls become old women, to the fleeting, breathless beauty of childhood" (ix). Other photo-books address being an American woman from the ethnic perspective of African American, Native American, and 
Hispanic women or from the professional and patriotic perspective of women serving in the United States Armed Forces (Summers et al.; Curtis et al.; Lewis; Browder and Pflaeging; Grant et al.). In all of these photo-books, the national seems to become secondary to ethnic or gender-based issues as the focus is less on being a woman in America, and more on being a child, a minority or working in a predominantly masculine profession.

Only a few contemporary photo-books have been published that claim to focus specifically on women in general as Americans. In 2012, Claiborne Swanson Frank published a collection of photographs of women in her American Beauty (co-authored with Genevieve Bahrenburg). And a few years earlier, in 2005, Bryan Adams published American Women. Both focus on women as Americans, even though they are primarily fashion books. ${ }^{2}$ A final photo-book of interest, Women, was created by Annie Leibovitz and Susan Sontag in 2000. They describe it simply as "a book of photographs of people with nothing more in common than the fact they are women (and living in America at the end of the twentieth century)" (Leibovitz \& Sontag 19). These more recent photobooks are important for the explicit, visual portrayal of the American woman and the different definitions they propose.

Unlike the above-mentioned works that focus on specific aspects of womanhood in America or even other monographs by women documentary photographers-such as Catherine Opie (1999/In and Around Home), Laurie Simmons (The Love Doll), or Carrie Mae Weems (Kitchen Series) - who focus on feminine identity in contemporary American photography, one photo-book stands out for its focus on photo-essays that aim to define the American woman today: A Day in the Life of the American Woman published in 2005 by Sharon J. Wohlmuth, Carol Saline, and Dawn Sheggeby. I choose to analyze this book both because of its portrayal of women as specifically American and its close relationship to the photojournalistic, photo-essay format. The book's visual layout, which mixes one main photograph or a series of photographs with a block of text to narrate a story, is reminiscent of the photojournalistic technique codified by picture magazines such as Life and still used today (Colin Bayly vol. 1 88, 117-124). The objectives set out in the introduction of A Day in the Life further link the photo-book to the photojournalistic, photo-essay tradition by aiming towards spontaneity (the "scoop") and mainstream appeal. The photojournalists' assignment was to "captur[e] in a single moment in time [...] ordinary women going about their everyday lives [...] over the course of a typical day" (Wohlmuth et al. 7).

5 Additionally, A Day in the Life of the American Woman: How We See Ourselves was a collaborative work by more than 130 women, most of whom were tied to the magazine industry. Among the project's three originators, Wohlmuth is an award-winning photojournalist who worked with the Philadelphia Inquirer for twenty years and had works published in magazines such as Life, Time, People and Glamour. Saline is a journalist for Philadelphia Magazine and her articles have appeared in the Reader's Digest, Family Circle and Self. Sheggeby worked for EpiCom Media, which participated in the publication of the book. The editorial team consisted of nine women photo editors from magazines including Time, Newsweek, Life, People, Parade, More, In Style and Vanity Fair. (Wohlmuth et al. 7, 176) They commissioned 56 women photographers-40 of whom are photojournalists, 15 are documentary photographers and one is an amateur photographer. Most of those who are recognized as documentary/art photographers 
have nevertheless had their work published in magazines. The result was a collection of over 200 photographs of more than 70 women.

6 Even though A Day in the Life of the American Woman does not contend to be a feminist work, ${ }^{3}$ one would assume that, since the notion of the American woman is not monolithic, the photographic representation of the American woman in A Day in the Life of the American Woman should be fundamentally different from Life's photo-essays of the 1940s and 50s, in part because of the feminist movement of the late 1960s and 70s, the exploration of feminist theories by artists, and their impact on American society. In short, a photographer's work may be fundamentally feminist without her being a selfproclaimed feminist. In fact, several photographers involved in A Day in the Life of the American Woman are renowned feminist artists-Donna Ferrato, Lauren Greenfield, Mary Ellen Mark, and Joanne Pinneo, to name a few-whose works expose cultural assumptions about gender and explore the nature of sexual and racial difference. Furthermore, the book's subtitle, How We See Ourselves, and its professed goal of presenting the American woman through the eyes of other women further raises expectations for iconic representation of a feminist agenda of empowerment or deconstructing social norms and stereotypes.

7 In light of the various (theoretical and/or artistic) works devoted to examining the American woman and the evolution of her place in American society, one could wonder if A Day in the Life of the American Woman offers a way to articulate the tension between the traditional patriarchal society and the modern American woman? Has feminism finally encouraged the visual representation of women conform to the reality of the complexity and diversity of the female life? By looking at the way the book produces identification, we will evaluate the degree of success or failure of the project to recognize the progress made by the American woman of 2005. This article aims to demonstrate how the photographic production of the American woman is able to reflect certain aspects and advances in women's history and feminist theory such as a new vision of sexual and familial arrangements, as well as the revision of feminism to embrace women of color's experiences and differences, while at the same time continuing to reinforce the stereotypical vision of women that has been articulated in popular American media for over half a century. Thus, this article discusses the limits of such a documentary project that in fact reproduces the conventional portrayal of the American woman. The first section focuses on photojournalism, its format and traditions, which lends itself to identification. On the grounds that the notion of the American woman shifts and vacillates over time and is dependent upon context, the second part will examine how the American woman was defined in 2005 within the pages of the book. The final part will reveal that, paradoxically, instead of glorifying the liberated, modern woman, A Day in the Life of the American Woman clearly illustrates that the patriarchal status quo is still strongly ingrained in the photojournalism/news/ magazine industry and that women and feminists still have a long way to go.

\section{Framing the American Woman: Photo-Essays and the Imagined Community}

Identification to a national community is a complex process that relies on various factors and multiple sources, and the media, especially (news) photography, is an integral part of this process in that it informs (visually) beyond the local environment 
(Smith, 1991). ${ }^{4}$ In his discussion of the interaction of capitalism and print on the origins of national consciousness, Benedict Anderson, who defines the nation as "an imagined political community," explains that, "[the nation] is imagined because the members of even the smallest nation will never know most of their fellow-members, meet them, or even hear of them, yet in the minds of each lives the image of their communion" (Anderson 6). A Day in the Life of the American Woman participates visually in this national communion by establishing a communion among women. The "community" of American women is "imagined" through three traditions: the photojournalism tradition of bearing witness, the format of the photo-essay and its content that reflects the humanist tradition of using universal concepts.

9 According to Claude Cookman, in his book American Photojournalism: Motivations and Meanings, photojournalists' primary objective is bearing witness and recording important events and people (3). The majority of the photographers commissioned for the making of A Day in the Life of the American Woman (36 out of 56) are professional photojournalists, making their living essentially as freelance or staff photographers for newspapers and magazines. Yet, history is not always written with a capital $\mathrm{H}$. The women photojournalists involved in the project were not capturing scoops or newsworthy events because they had been instructed to, "(turn their) lenses away from the headline makers to capture extraordinary images of an ordinary day in the lives of American women" (Wohlmuth et al. inside front jacket). A Day in the Life of the American Woman documents a specific time and place: the United States on April 8, 2005, an "ordinary" day with no apparent historical importance, beyond the fact it provided the opportunity for these women photojournalists to simultaneously record how American women across the country spend their day.

The book is able to claim to be a testimony to reality and a source of identification thanks to photography's long-recognized capacity of mimetic re-production of the referent located in front of the lens. A Day in the Life of the American Woman specifically tells the viewers that they are looking at American women and that they should recognize themselves within the pages in the hope of creating a bond among American women. On the inside flap of the front jacket cover, the creator of the project, Carol Saline, writes, "A Day in the Life of the American Woman shows us our mothers, our daughters, our sisters, our friends and ourselves." The introduction to the book also bears the title "How We See Ourselves" and aims at explaining that "we," the photojournalists are just like "you," the reader. Even though grounded in reality, the everyday lives depicted may not correspond to those of the viewers'. Yet, no matter how far removed the subject's life might be from the viewer's, the photographs provide elements of recognition and identification for the viewer. The photo-essay "The Queen of Bluegrass," for example, presents a moment with Rhonda Vincent, a bluegrass singer (Wohlmuth et al. 152-157). Very few women could truly identify with her career, her lifestyle of touring and living on a bus, but the photo-essay makes her life recognizable as many women find themselves overwhelmed by daily chores. She is seen inside her touring bus sitting at a table multitasking on two computers while talking on the phone. The viewer can notice crumpled papers lying on the ground insinuating she has other priorities to deal with before picking up paper scraps. Other photographs in which she is looking exhausted and lonely, or simply enjoying herself provide readers visualizations and articulations of selfhood that most women can identify with. 
11 Identification through bearing witness is further enhanced by the photographic nature of the images resembling snapshots of everyday life instead of works of art by professional photographers. Despite the large panel of prize-winning photojournalists included in the project, few images really stand out for their aesthetic quality. ${ }^{5}$ Several photographs are undeniably moving, sensitive portrayals of intimate moments in the lives of ordinary women and they tend to draw the reader in emotionally. However, more frequently many of the photos intentionally resemble amateur shots through errors in the framing and the lighting or the presence of an awkward blur. The content as well points to amateur photography: girls out partying or a family meal with the woman in the foreground looking or speaking directly to the photographer/viewer. The gathering of these snapshots capturing small moments in everyday life, taking kids to school, picking up clothes, driving to work, exercising, eating, reading, praying, laughing, working..., draws upon the tradition of using photography to create a family album $^{6}$ or, more recently, posts on Facebook and Instagram; in other words, they create a sort of familiarity between the viewer and the viewed. The format conceals the constructed nature of photographs and the reader is given a glimpse of life as experienced by many American women across the country. The reader may thus experience an almost voyeuristic pleasure by gazing upon the intimate lives of other women and perhaps even a sense of reassurance in recognizing similarities with her own life.

12 Focusing on the ordinary lives of the subjects and mirroring that of the readers is a technique long used by photo-essays. Indeed, from their inception in the late thirties, picture magazines also focused on everyday life. ${ }^{7}$ Loudon Wainwright, a former assistant managing editor of Life magazine and author of The Great American Magazine, wrote, that “... Life's greatest resource for its best picture stories would always be the lives of ordinary people, their work, their pleasure, their follies, their anguish. Such stories touched virtually every reader." (Wainwright 71). Wainwright explains the technique of the magazine Life to hold up mirrors to its readers, “...the faces of Americans of all kinds would stare back at millions of readers, who here and there, would recognize themselves." (26).

13 A Day in the Life of the American Woman's ability to reinforce self-identification between the book's subjects and the reader also lies in its classic documentary, photo-essay format of mixing pictures and words. This format was popularized first in photobooks ${ }^{8}$ and then in the newsmagazines, ${ }^{9}$ setting the photojournalism traditions of a rhythmic layout that varied the size of the image and an interweaving of texts in order to construct a narrative of objective "truths." The latter being quite ironic considering the technical aspects of the photo-essay that codify "truth"-use of sequencing, text, and the photographer's gaze-are all subjective choices guiding the understanding of the images.

14 Just as narration through the ordering of a series of photographs is inherent to the photo-essay, the organization of the photo-essays in A Day in the Life of the American Woman creates a double narrative. First, there is the "story" of each woman depicted in one to eight photos either illustrating a single moment or accompanying her through different moments of her day. Secondly, the individual stories are arranged in the book in a manner to create a temporal dynamic of the different phases of the life of the American woman-young adulthood, establishing a career, getting married, creating a family and childrearing, working, aging and coping with death. 

will witness the passion that [American women] pour into work, family, relationships and community" (Wohlmuth et al. 8). Indeed, readers discover photos of lovers and marriage; child rearing and motherhood; friendship and "having a good time"; juggling work and family; exercising and exhaustion; dealing with sickness, aging and death; faith, heritage and patriotism; sacrifice. These themes are not just a means used for a chronological organization the book; they are the basis of what the creators describe as "a rich tapestry of the joys and accomplishments, struggles and triumphs that make up the fabric of women's lives today" (Wohlmuth et al. front jacket). The book's implicit 
thesis is that American women-whether young or old; white, African American, Hispanic or Asian; blue collar, pink collar or white collar; single, married or gay; from the East coast or West coast, the city, suburbs or farm-are basically the same. By showing the sameness of the American woman's experience through love, family, motherhood, work, play, suffering and death, A Day in the Life emphasizes the commonalities of their experiences. Elements of counter-identification or possible divisiveness seem to have been erased, blurred, or diverted by the repetitive emphasis of the universality of the condition of the American woman that is reduced to love, loss, family, work, play, and solitude.

Many reasons have been advanced as to why one should be wary of the veracity of what is depicted in a photograph. From the philosophical inquiries of Jean-Paul Sartre and Roland Barthes to more contemporary criticism by Gisèle Freund, Susan Sontag, W.J.T. Mitchell, Fred Ritchen or Ariella Azoulay exploring photography's uses, effects and relationship to society, today it is widely recognized that a photograph does not provide an objective 'truth.' Nevertheless, viewers still tend to intuitively believe that what they see in a photograph is the result of a reality that occurred in front of the camera. We continue to use documentary style photography to bear witness and seeing is still accepted as believing, even in the era of digital photography which can easily be manipulated. Thus, in A Day in the Life of the American Woman identification occurs from seeing and recognizing oneself in the American woman of 2005 through "real life" daily "stories." Through universals of love, family, work, play, aging and death, A Day in the Life of the American Woman acts as a family album uniting American women into the (American) Family of (Wo)man. Displayed on a coffee table to be read by visitors, shared between friends, offered as a gift, A Day in the Life of the American Woman provides a permanent record that can be looked at again and again. The intimate is placed into the public sphere for women to contemplate other women and the experiences of women as specifically American. Yet, what characterizes this 'family'? What image of American woman are the readers presented and urged to identify with?

\section{The (American) Family of (Wo)man}

20 A Day in the Life shows that women belong to a common family-the family of women. Families, just like nations, are usually based upon ancestry, heritage, kinship and historical bonds. However, because in the United States there are not necessarily the typical factors of national belonging such as shared culture, language and blood ties, according to a more conservative vision of the American nation, it is supposedly held together through an ideological bond vested in the commitment to core values which influenced the framers of the Declaration of Independence, the Constitution, and its Bill of Rights. These include liberty, egalitarianism, individualism, populism and laissezfaire (Lipset 19). To this end, symbols, myths and values permeate American culture and institutions trying to implant (a façade of) unity and fraternity among the heterogeneous population (Smith, 1999 167). While the title of the book, A Day in the Life of American Women, anchors the readers' expectations for these women to be specifically American, little effort has been made to visually locate them in the American national sphere. In addition to one picture with a flag in the background of a gymnasium (Wohlmuth et al. 43), the only other visual references to national symbols emphasize civil duty or sacrifice for the nation on badges (25, 77-78), a voting pin (29), the Capitol 
building (52) and the illusion of sacrifice $(109,136)$. Several images of women in military fatigues are shown, but their nationality is unrecognizable. Thus the photobook A Day in the Life of the American Woman relies only so slightly on iconic representations of the nation to situate these women within an American environment. However, it does reinforce the commitment to American ideology and core values by providing visual "proof" that these women embody the values and freedoms the country has to offer and that are vital to American identity at the beginning of the twenty-first century, and more precisely in 2005. A Day in the Life of the American Woman is a testimony, even a celebration of the freedoms and opportunities American women have gained and benefit from. The principal values underlying a vast majority of the stories are Individualism and Egalitarianism.

In American iconography, the cowboy is probably one of the most symbolic representations of American individualism. Thus, the cowgirl obviously has her place in A Day in the Life in the photo-essay "Home on the Range" (Wohlmuth et al. 100-101). Beyond the cowboy cliché, other facets of American individualism are embodied by the women on these pages. Unlike in the 1940s Life magazine article in which the American woman's "agelessness" was an identifying criterion, ${ }^{11}$ in the pages of A Day in the Life of the American Woman she no longer aspires to eternal youth; women of all ages take care of themselves in order to deal with what life has dealt them and enjoy what they make of their lives. Many of the women's stories reveal some sort of hardship or obstacle that they had to overcome and that other women may have had to cope with as well: a miscarriage, looking for employment, juggling professional and family life, illness, loss, etc. The accompanying essays clarify for the reader what the image could not reveal. Despite 44-year-old Kimberly Brooks' "relaxed style [which] makes her stand out," she says, "she's been touched by enough tragedy-a miscarriage, a brother who went to Vietnam, a 46-year-old sister who died from breast cancer-to want her own family to enjoy living in the moment" (Wohlmuth et al. 13). Sara Blakely also claims, "I have been through grief that brings you to your knees. It's given my life an urgency and sense of the preciousness of time that's unusual when you're 34" (21). Jeanne MoutoussamyAsbe in her photo-essay, "My Mother," photographed her mother who suffers from Alzheimer's disease. She questions, "Where did my mom go? [...] I still see glimpses of her essence. She is stubborn. She will certainly speak up for herself when she doesn't like something. She still likes to comb her own hair. She still likes to be well dressed and still prefers skirts to pants [...]. Her feistiness and stubbornness are what have brought her this far" $(142,144)$. These examples illustrate that the American woman may grow old, but she does so with dignity and bravado all while embracing a combative spirit. More importantly, these essays guide the reading of the image according to American values and focus on how she overcame that obstacle thanks to her individual strength. Throughout the essays, mentions of the American woman's "resilience," "relentlessness," "perseverance," "hard-work," "self-reliance" abound. In the photo-essay "Love Goes On," Maureen Fanning, who lost her husband during the rescue efforts of the World Trade Center on September 11, 2001, and her second son Patrick, who like his elder brother is autistic, take a break from daily chores to enjoy one of the simple joys of childhood-the merry-go-round (106-109). In contrast to the other seven pictures that show Maureen coping quite joyfully with her busy life schedule, the primary focus of this story is a testimony of a moment's weakness. The photograph is visually destabilizing due to askew lines and diagonals. The downward slope of the background follows the direction of Maureen's closed eyes as if she could 
not bear to look as life heads downward, out of control. The world, like the merry-goround, seems to be going faster than desired as, in a reversal of roles, Maureen clings to her son for a source of stability and strength. In the accompanying essay she is quoted as saying, "I can't give up." Her grief and her strength to move forward despite her difficulties are intended to create empathy and inspire.

This self-reliance also translates into a modern structuring of American society in which American women need no longer be dependent upon patriarchal institutions of marriage or government: Adela Vazquez, in "Border Patrol," informs readers, "I work all the time, make the money, and don't do the traditional wife thing" (24). Or in the case of Lupe Valdez in "New Sheriff in Town," she emphasizes that she "came from nothing" (79) and informs readers that growing up in poor family she "proudly refused public assistance" (78).

In addition to the myth of the self-made woman, the ideology of freedom and particularly sexual freedom as the achievement of a woman's being is prominent within the pages. Thanks to feminist struggle in the sexual revolution of the 1960s, the pill and later Roe $v$. Wade, women were empowered to make choices regarding reproduction and contraception, in other words, when and if to have children, as is evidenced in the essays and photographs. American women are in control of their bodies and their sexuality. "Dr. Anne," writes Colleen Paretty, "a woman who is equally at home in black stilettos or paddock boots-is a woman of her own invention" (Wohlmuth et al. 86). The American woman chooses to be seductive (or not), but avoids objectification because she holds the power through her personal choices. They are not afraid to discover the sexuality of their body and to defy stereotypes of female beauty and stereotyped images of the feminine ideal. In "Boa Instructor" Lauren Greenfield photographed Misty Tripoli, who confides that one of her students admitted that she "never realized [her] body is sexy exactly the way it is" (49). Femininity can be considered a performance of womanhood American women get the privilege to play with. Femininity, along the lines of Judith Butler, becomes an enacted "fantasy or incorporation" in which "acts, gestures and desire produce the effect of an internal core or substance, but produce this on the surface of the body [...]. Such acts, gestures, enactments, generally construed, are performative in the sense that the essence or identity that they otherwise purport to express are fabrications manufactured and sustained through corporeal signs and other discursive means" (Butler 136). First class Jennifer Lipzer, a medic in Baghdad, is pictured lying on her bed with her long hair cascading down her back as she confesses "I love painting my toenails" (Wohlmuth et al. 110). Rhonda Vincent, the bluegrass performer, lets the viewers see femininity as performance as she opts for her stilettos during concerts, but otherwise prefers jeans and t-shirts. In the photo-essay "Girls' Night Out," (160-161) Mary Ellen Mark photographed "the exuberance of gyrating couples in tight jeans." For Mark, "[t]his is about how young, middle-class working women go out and party. How men enjoy dancing for women. I see it as a kind of performance art. Nobody takes it seriously." Mark adds "everybody is putting on a big show acting sexy and suggestive but not being bad" (160). It is interesting to point out that this visual erosion of stereotypical gender norms-seen through the reversal of roles in which women may be seducersrequires text to orient the viewers' understanding of the images towards acceptance.

These fruits of feminism appear to be taken for granted by the creators of A Day in the Life, who seem to reflect a certain expression of post-feminism: not so much the 
antifeminist "backlash" (Faludi) of the late twentieth century embraced by women such as Phyllis Schlafly which contributed to the rise of the "New Right," but rather that vein of post-feminism which rejected feminism on the basis that the movement's objectives of the 1960s and 70s had been met. They write in the introduction: "Why wait to find a husband before buying a house, when you can purchase one and fix it up yourself? Why not move to the countryside, or run for office, or start your own company, or preach the gospel-if that's what makes you happy?" (Wohlmuth et al. 8). From the first to the last page of the book, individualism as self-fulfillment, selfreliance and agency is seen as an overall objective for American women that all may obtain.

This message of individualism translates into a confirmation that the United States is an egalitarian society offering equal opportunities, social mobility and the recognition of the diversification of social and familial structures.

The vision of an egalitarian society extends to the diversification of society in which American women are racially diverse. Despite its history as an immigrant nation integrating new arrivals, tensions have been exacerbated since the 1980s with the everincreasing influx of Latinos, resulting in a new focus on ethnic differences. To some, the emphasis on ethnicity and difference weakens the possibility of achieving a set of values that could represent a distinctive "American Way of Life." Conservative political scientist Samuel Huntington contends that society is at risk because competing cultures and languages weaken, even transform, American identity. The diversification of American society captured in A Day in the Life of the American Woman challenges the WASP stereotype from a racial perspective. While the majority of the photo-essays are devoted to visibly white women (almost 40), stories of African American, ${ }^{12}$ Asian, ${ }^{13}$ and Hispanic $^{14}$ women are plentiful. Likewise, another photo-essay, "All About Mee," focuses on a Laotian immigrant, Mee Moua (Wohlmuth et al. 52-55), and yet another, "Native Voices," on an Alaskan Haida native, Cherilyn Holter (32-33). The emphasis is on illustrating a "diverse group of women," the recurring phrase of the creators. This is a welcome change from the 1940s and 50s WASP stereotype. The American ideal of $e$ pluribus unum is an abstract concept, not a reflection of a reality. However, by presenting diversity through the universality of women's common condition of dealing with joys and loves, coping with sorrows and obstacles, the photo-essays de-emphasize what could typically be divisive (ethnic group, culture, class...).

The image of the traditional family that requires a breadwinning, decision-making father and a mother in charge of the domestic sphere, often portrayed as submissive, has been repeatedly challenged by feminists, yet tends to re-emerge regularly in the American media. At the end of the twentieth century and beginning of the twenty-first century, tremendous growth in women's labor force and their entry into maledominated fields led to profound changes in family and personal lives, favoring the diversification of sexual and familial structures. A Day in the Life of the American Woman seems to recognize the diversification of the family structure (even if several traditional families are included). The American woman is not systematically portrayed as wife, homemaker and mother all balled up in one package. Her options are numerous and the photo-essays recognize other realities. The American woman can be single, ${ }^{15}$ divorced ${ }^{16}$ or widowed $;{ }^{17}$ married, living as a couple but not married or as a same-sex couple with children. ${ }^{18}$ She is shown as raising between one or six children or with no children at all. They may be biological or adopted children. If she has children, she 
raises them with her husband, her partner (male or female) or alone. She stays at home because she has chosen to or she holds a full-time job or she has a career. The American family appears to be anything but monolithic and traditional.

An egalitarian American society is shown to include professional equality as well. Repeated images of women in jobs or professions typically occupied by men are not only the sign that women are just as capable as men, but also provide visual proof that opportunities for women in America are limitless. Even the male-dominated myth of the self-made man has its female counterpart in Sara Blakely, who by 2012 became the world's youngest self-made female billionaire thanks to the success of Spanx. The photo-essays emphasize women choosing to be in jobs or professions traditionally occupied by men. They may be butchers, ${ }^{19}$ race-car drivers, ${ }^{20}$ electricians ${ }^{21}$ or sheriffs, ${ }^{22}$ remodeling a home ${ }^{23}$ or serving the country; ${ }^{24}$ the point is that they are just as capable of doing what they have chosen to do as men. In an attack while flying a Black Hawk in Iraq, Major Tammy Duckworth lost her foot, part of her remaining leg and severely injured an arm. She explains: "Flying was the only combat job open to women. Nobody wants to get blown up or shot at, but I decided if I was going to be a soldier, I didn't want to take fewer risks than men. I wanted to be equal. I am just as much a soldier as the guy next to me" (Wohlmuth et al. 137). Leilani Münter, a race-car driver, challenges gender roles. "As a kid in Rochester, Minnesota," Carol Saline wrote, "Leilani preferred football and soccer-and later snowboarding and scuba diving-to girly games like hopscotch. Her three older sisters had dolls; she had an Atari with a gun that blew up asteroids" (102). The accompanying essay underscores the difficulty to succeed in a male-dominated profession. "Nascar racing is an uphill battle if you're not a man," Carole Saline adds (104). Yet, like Karen Owens who bought a fixer-upper to renovate herself and "always thought there was a secret club of men who had skills with power tools" (93), these women refuse to surrender their dreams to conform to patriarchal roles. Jo-Ann Feigofsky, a Lieutenant in the US Coast Guard oversees a 17-man crew. She is the only woman, which, she says, "isn't an issue" (64). These women "never knew a time before 'girls can do anything boys can!' The fruits of this kind of confidence are [shown to be] enjoyed by almost every American girl or woman alive" (Baumgardner 17). The creators wanted to prove that "[w]omen today have learned they can write their own recipe for contentment, set their own priorities and take control of their lives with courage and creativity" (Wohlmuth et al. 8).

29 Although the book does not explicitly claim to be feminist, it shows post-sixties feminism has allowed the representation of the American woman to change from that of the stereotypical white, middle-class housewife/mother to one that reflects American society's heterogeneity. Each woman has "intersecting" identities based on her ability, age, class, race, sexuality which cannot be separated (Kinser 24). These have a combined effect on women's lived experience. The multiple identities of Dee von Entress, for example, affect her empowerment or oppression. Her occupation as an electrician needs to be accounted for parallel to the fact that she is also white, middleclass, lesbian and pregnant.

Thus each woman's lived experience is unique (but universalized) and by visually and textually appealing to these multiple identities of many women, the book enlarges the scope of identification and the experience of pleasure. As American women gaze at these photographs and read the stories of these "real," "ordinary," yet extraordinary 
women, and recognize their mothers, friends, sisters and themselves, they have the impression of integrating the (American) family of (Wo)man.

\section{Diversification Questioned}

31 A Day in the Life's portrayal of the American woman offers an optimistic vision challenging the stereotypical image of women. Photojournalism's tradition of using humanist universals is present in the photo-essays and encourages sentiments of recognition and identification by neutralizing the tensions that may arise in a diversified society where women have multiple roles. However, another look at the book's photo-essays reveals that the textual and visual argumentation raises certain questions. Behind the encouraging message of unlimited opportunities accessible to the liberated American woman, lies a more imperfect reality. Various elements of the photo-essay visually and textually enforcing the message of the liberated American woman embracing multiple identities in fact re-emphasize the appeal of the traditional American woman, reminiscent of mid-twentieth-century stereotypes. ${ }^{25}$

While lending itself to identification, the use of universals and everyday life in photography tends to oversimplify (if not ignore) complex issues. Roland Barthes argued that "The Family of Man" used universals to conceal repressive economic and political conditions by portraying them as natural. By using Nature-the presumed universality of human experience-as a myth to conceal the injustices of history, Barthes argued, "The Family of Man" denied historical determinism by insisting that birth, death, work, religion, and other humanist themes are natural and thus beyond challenge. Thus, Barthes reminds us that by focusing on the essence of universals through the "poetic" and "sentimental" language of the photograph, historical fact and injustices are ignored (Barthes, 1957 174-175).

In a book by women and about women, one would expect some attention to be paid to issues that directly affect women and their lives in 2005 such as the Bush administration's conservatism and cuts in funding for single, poor, working mothers; the rise in anti-abortion sentiment; "prom-moms" and teenage pregnancies, lesbian custody rights, continuing inequalities in the workplace, to name just a few of the issues affecting women in 2005 (Finlay). It is not as if all issues are totally ignored. However, with the exception of breast cancer, the few that are included (domestic violence, pregnancy, childcare and prison moms reintegrating society) are in fact backdrops to the stories. Take for example Donna Ferrato's ${ }^{26}$ "Reunited" photo-essay about Vikki Marshall. Domestic violence was alluded to, but the focus was actually on mother/daughter love and forgiveness, and a tribute to caregivers. In this case, as in many others, the use of universals has concealed the repressive social, political and economic inequalities and injustices caused to American women. The universal and humanist traditions along with the glorified vision of American woman throughout the book provide a post-feminist perspective that acknowledges the accomplishments of feminism (recognition of diversity and the multitude of family models, the freedom to choose one's occupation, etc.) as entitlements of American society, thereby suggesting that nothing more needs to be done to further improve women's condition when, indeed, injustices and inequalities continue to exist.

In its glorification, A Day in the Life of the American Woman has also misrepresented the realities of American life that affected women in 2005. One of the book's seemingly 
major breaks from the traditional representation was the presence of women from racial backgrounds other than white-Hispanic, African American, native Alaskan and Asian. Recognition of racial diversity was acknowledged in the photographs by mirroring more or less the statistical breakdown of racial diversity in America at the beginning of the new millennium. Out of over 70 stories, 21 (30\%) were of women visibly belonging to a race other than white. While this is actually higher than the actual population (75\% white according to the 2000 United States Census), the majority of the stories devoted to minorities were about black or African American women. Furthermore, while Hispanics are the most populous minority group (12.5\% according to the 2000 United States Census), only two of the stories (less than 3\%) were about Hispanic women. However, this racial diversity was never a primary focus of any story and no essay directly referred to race or to the difficulties that arise in American society due to race. Is this absence of reference to race-related issues a way to erase or neutralize differences and further universalize the condition of American women?

Further analysis of the question of racial diversity reveals the photographs' tendency to reinforce racial stereotypes instead of counterbalancing them. A typical example is the fact that the stories focusing on Asian women maintained the stereotype of Asian excellence-as state senator, ${ }^{27}$ top musicians, ${ }^{28}$ or heroic soldiers ${ }^{29}$-while those of black or African American women tended to depict them in lower-class scenarios. In "Fighting Chance," the reader sees Whitney Drayton boxing in the gym, something she has been doing with her dad from the time she was old enough to remember; that is how he "protected her from the drug world that destroyed his sons" (Wohlmuth et al. 42). In "Moved by the Spirit," Sister Kaye Stramler from Power House Ministries "prays in tongues" as a "messenger of God" (68-71). "Starting Over" shows Hispanic and black women photographed in transitional housing after leaving prison (82-85). Lorena Macias, homeless when younger, works as a social worker helping out homeless teens and adults. In "Off the Streets," she is photographed distributing simple things like deodorant, tampons, condoms and bleach kits (122).

Instead of challenging stereotypes, the photo-essays affirm the traditional white, middle-class representation of the American woman. White, middle-class values and practices dictate the dominant cultural thinking about families and motherhood and are reflected in A Day in the Life (Kinser 22). The "Kuleshov effect" ${ }^{30}$ or the power of juxtaposition and its influence on identification and counter-identification are clear in the first two stories of the book for example. The opening story, "Flower Power," could not be more traditional: Kimberly, a blond, white upper- or middle-class stay-at-home mother attends to the needs of her three children as her bread-winning husband (one of the few men in the book ${ }^{31}$ ) rushes off to work. On the opposite page from the traditional mom, in the photo-essay "Granny Heart," the viewer meets "Mama," also taking care of children, but here we discover a different image. First of all, her portrayal and that of other African Americans is reminiscent of when black women were confined to domesticity and/or caring for white women-see also "Soul Sisters," (Wohlmuth et al. 126-129). Her grey hair indicates that she is most probably too old to be the children's mother. The reader discovers, along with domesticity, the black community's definition of family, which extends beyond the "bloodmother" as source of substance and upbringing to the extended family and "othermothers" (Hill Collins 318). Indeed, it is explained that "Mama's" son is incapable of raising his children, so she has taken over the role of mother. On one page, the reader sees Kimberly's playful, happy family "bopping spontaneously" in the modern, well-equipped kitchen. On the 
opposite page, the poor conditions of "mama's" kitchen stand out-a rickety, over-used ironing board in the middle of the kitchen, the clutter of unused hangers in the open cupboard, a bottle of borax bleach just left out on the floor next to the sink, old appliances and un-matching chairs. Neither "mama" nor the children appear to be having fun, let alone joyful, as each one independently takes care of him or herself. The prominence of similar images increases the desirability of the American woman along traditional lines as the book extols a conservative ideology.

As demonstrated here in section two, another key message of the photographs in A Day in the Life of the American Woman is that everything is possible for the American woman. However, the texts and essays provide little indication of the social or political barriers that make many of these choices difficult if not impossible for most. In the United States, there is still no Equal Rights Amendment, therefore constitutionally woman and men are not equal. Women are faced with inequalities and obstacles when vying for promotions, trying to combine salaried work with parenthood, at the end of the month in their paycheck, at retirement...32 The photo-essay "In the Green Zone" explains: "Private First Class Jennifer Lipzer, an Army medic stationed in Baghdad, is proud to be the only woman on her team. Lipzer herself points out her need to prove herself, not against a specific objective, but against other men's performance, 'When we started training, I had to prove myself. Now they treat me like a sister,' she says, recalling the day she aced the marksmanship test and four men failed" (Wohlmuth et al. 110). The photo-essays make no mention of cases of discrimination and rape in the Armed Forces which are severe problems many women officers face. The same point is raised in "Built for Speed" about Leilani Münter, a race-car driver. "A year ago [Leilani] showed up to race at the Texas Motor Speedway and got a lot of who-the-hell-is-this-babe looks from the regular drivers. But all that disappeared when she qualified fourth, and finished sixth out of 26 cars" (105). Thus, the American woman's place in the "man's world" is only accepted/acceptable if she is able to prove as able as, or even superior to, men. This need for women to constantly prove themselves is proof in itself that sexual discrimination continues. According to the book, women must excel to utmost perfection (or at least perfection established by men) if they want to move beyond the traditional roles.

A final example of the limitations to the glorified vision of American women presented in A Day in the Life of the American Woman is a photographic representation that lends itself to an intentional misreading of American family structure, especially in the recognition of alternative definitions including LGBT families. First of all, bisexual and transgender mothers are non-existent. And the two lesbian families included in the book-Dee von Entress, "Live Wire" (Wohlmuth et al. 92); Michelle Drury and Marci Lavigne, "Family Practice" (124)-are all but invisible. The reader learns through the accompanying text that both lesbians in the book are in couples with children, yet the relationship remains visually ambiguous. Only one photograph illustrates an ordinary day in von Entress' life and the focus is on her as an electrician in her work place, not her family. Her pregnancy is still unnoticeable and her partner and daughter are not shown in any picture. The portrayal of the second lesbian couple is interesting in that it visually reproduces the traditional white, middle-class family all the while drawing attention to alternative versions, perhaps in an attempt to normalize them. In fact, the text is required in order to anchor meaning. Without it, the reader is not urged to recognize a lesbian couple-in fact they look more like sisters-but to focus on their careers as medical practitioners and their admiration of children. Even if same-sex 
marriage was one of Americans' major political preoccupations in $2004^{33}$ and is recognized in A Day in the Life, such images neutralize and reiterate the traditional vision. Again, many of the issues affecting lesbian couples have been ignored, for example the difficulties of bi-national lesbian couples who are unable to marry, be citizens of the same country and live together. These examples illustrate not only the ideology put forward by A Day in the Life of the American Woman, but simultaneously point to some of the anxieties of American society in 2005 in the context of a War on Terror where America's hegemony has been challenged and thus the need to affirm the solidity of America's foundations.

Admittedly, A Day in the Life of the American Woman offers a vision of American women in which advances have been made on their behalf while simultaneously reinforcing certain American values and myths directly linked to national identity. Yet, despite the veracity of the women's lives, the photo-essays present a rather idealized reality. More worrisome, is a second message infused predominantly throughout the entire book: the traditional claim that motherhood is the pinnacle of womanhood. On almost every page, A Day in the Life of the American Woman devotes text and/or photographs to mothering. Pat Kruger in "Leaving the Office Behind" tells the reader: "Being a mother is the most important job there is" (39). In "Feeding Time," Holly Smith, a star chef in Seattle boasts: "Oliver [her son] is the best thing I've ever done" (130). Or again in "Diva Mom," Deynce Graves, an international opera star admits: "Ella has given birth to me, not the other way around. I love being a mom" (133). The ultimate take-away message for the readers of A Day in the Life of the American Woman is an essentializing notion of nurturing and that among all the factors illustrated or mentioned that form the American woman's identity, above all, motherhood, defines the American woman's personhood.

Even in the photo-essays about women without children, A Day in the Life championed motherhood. They too are positioned in maternal roles. Sheriff Lopez turns to the officers and addresses them "like a worried mother" (76). Pat Derby, who runs her own non-profit called PAWS-Performing Animal Welfare Society-expresses pride in her elephant: "She is like our daughter, our little princess. If she were a human child, she'd probably be at Stanford or Yale by now" (35). For those women too young or not yet in a couple, motherhood seems to be their ambition. The four-page story about Sara Blakely and the multi-million dollar company she created finishes with her admitting, "I'm kind of ready to embrace the next stage, which I hope will be marriage and motherhood" (21), an addition altogether unrelated to the rest of her story. Further, Dr. Anne confesses that of all the aspects that make up her identity, motherhood prevails: "Most people would introduce me as a physician or surgeon," she says. "I define myself as Ryan's and Evan's mother" (88). A Day in the Life of the American Woman exalts motherhood as natural and a defining experience of womanhood.

41 To a certain extent, this vision reflects a twenty-first century conservative vision of women that tends to refocus on motherhood. According to Kinser,

at the turn of the $21^{\text {st }}$ century "expert" advice was increasingly child-centered and women were presumed to find their complete fulfilment in motherhood. The "new momism" seemingly celebrated and glorified motherhood, but in fact it promoted and ennobled standards of perfect motherhood that were impossible to reach (Kinser 122).

Children have become sacred and the duties involved with raising them penalize women at work for having family responsibilities and push many American women into 
the home and out of the office (Douglas and Michaels; Kinser). Pat Kruger's story exemplifies the situation of the twenty-first-century American woman who moved in and out of the workforce according to her children's needs. "Pat was living her dream. She had a high-powered job as head of litigation for American Standard, with a sixfigure salary and lots of glamorous business and personal travel. She had a husband she loved, and a great West Side apartment in Manhattan, overlooking the Hudson River. Then motherhood rewrote her script [...]. Reluctantly, Pat realized it was time for a change. She abandoned her job" (Wohlmuth et al. 36). Despite her personal desires, textual and visual messages conveyed by the media and books similar to A Day in the Life most likely contributed to her choosing to conform to a more traditional, stay-at-home mom role.

This perpetuation of the conservative definition of motherhood requires the American woman to be generally the one to take the time to care for the children when sick, to attend field trips and make cookies or cupcakes to take to school for their birthdays, help them with their homework, drive them to soccer or swim team practice. "Kimberly is a traditional mom. She's warm and loving. She stays home with the kids, folds laundry, picks up cluttered rooms, tracks her children's social activities on a huge color-coded calendar and raises money for their sports teams" $(10,13)$. Kimberly represents the phenomenon of child-centered, time and labor-intensive mothering that Sharon Hays names the "ideology of intensive mothering." Kimberly and her calendar (worthy of a corporate manager) of birthday parties; softball and basketball practice; flute and swim lessons; school district board meetings, etc. clearly illustrate this phenomenon of momism. "A 'good' mother certainly could work, as long as she manipulated her work life so that children remain her primary focus" (Kinser 120). The women in A Day in the Life of the American Woman are either seen as combining work and child-rearing with ease or happily devoted to their family, like Kimberly.

The photo-essays in A Day in the Life of the American Woman make it appear natural that the women who want to be "good" mothers are capable of juggling career and children perfectly or are happy to accept a hiatus in their career to devote all their energy to raising their children. The difficulties of caring for children while living full and purposeful lives are brushed over. The balancing act appears natural. The book presents an over simplified view of motherhood reducing/ignoring difficulties that are also different depending on race, class and other social factors which influence women's control over their choices/desires. In fact, according to Susan Maushart, the image of competent motherhood is unattainable yet repeatedly presented as natural, thus compelling women to pretend, by wearing a "mask of motherhood" allowing them to portray ease and naturalness in their role as mothers (Maushart). Women are not necessarily disappointed with their work, but the frustration and dissatisfaction is due to the fact that the workplace has not made the necessary changes to accommodate the realities of society and the needs of women through improved daycare, flexitime, etc.

A Day in the Life of the American Woman sends an ambiguous message to the readers. It celebrates the sexual freedom and control American women have over their bodies and their opportunities for self-determination, yet the sanctification of motherhood discourse makes it appear that alternative choices to motherhood are either temporary or unsuitable to the nature of woman. Consistent with the mainstream media, popular culture and politics, A Day in the Life of the American Woman continues to convey the message that the traditional values of marriage and motherhood are the pinnacle of 
American womanhood. By praising motherhood as any woman's ultimate aspiration the book undercuts its previous visual and textual affirmations of the self-fulfilled, liberated woman in an egalitarian society.

\section{Conclusion}

Photo-essays are constructed to encourage reader identification with the subject through various techniques such as realism, anchorage with text and the universal values of humanist traditions used by most photographers today. The initial reading of A Day in the Life of the American Woman seems to indicate an encouraging direction of identification other than the traditional twentieth-century images of the American woman and family shown in the mainstream media and which have had such a tremendous hold on our imagination (Kinser 25). The team of women authors compiled an array of images illustrating a diverse group of women of various ages, sexual inclinations, abilities, and from different classes and races. Feminism seems to be out there in their daily acts and choices of self-determination.

Oddly enough, the book simultaneously achieves its goal of "celebrating women" (Wohlmuth et al. 8) and manages to perpetuate a stereotypical vision of women in which the prevailing message is that motherhood is the ultimate role of the American woman. How can we account for such a conventional approach to American women? On the one hand, the complexity, the discrepancies and the paradoxes within the photographic discourse of A Day in the Life of the American Woman reflect the complicated situation that still exists for American women today. This "new momism," according to Susan Douglas and Meredith Michaels, was a media-generated phenomenon. As we have shown, A Day in the Life sustains this myth. Part of the answer lies in the subtitle, "How We See Ourselves," in which "ourselves" refers to the women in the photojournalism/news/magazine industry that made the book. While it could be argued that some women have made their voices heard in the art world, ${ }^{34}$ the world of photojournalism/news/magazine industry still complies with the patriarchal status quo. Despite the existence of organizations such as WPOW (Women Photojournalists of Washington), the industry has yet to make advances to fully recognize women. One reason is because, even if women's magazines are no longer edited by men, the ownership and advertising influence is still male-dominated (Baumgardner 110). ${ }^{35}$

This also holds true for the publishing sphere as can be seen in A Day in the Life of the American Woman. For, even if the book was a female-dominated project, it was not exclusively produced by women. Other than the creators, photo editors and photographers, all the other top positions were held by men: the producers (2), creative director (1), director of photography and 4 of the 6 members of EpiCom Media, the company producing the book, were involved in the project's creation, publishing and financing. Yet, their presence does not suffice to account for the underlying patriarchal message. As Amber Kinser points out, "[a]t the end of the $20^{\text {th }}$ century, media, corporate and religious dialogue seemed to adopt the propaganda campaign strategy used before and after World War II to ground women once again in their domestic roles" (120-121). It appears that patriarchal codes have yet to be fully challenged in the news/photo/magazine industry as the female gaze still adopts the male gaze and reproduces the patriarchal status quo. Two articles from Time and The Atlantic Monthly illustrate that as the twenty-first century moves on, the message that women are 
happiest at home raising children continues to cover the pages of mainstream media. The subtitle to Time magazine's 2009 special report cover story "The state of the American Woman" informs that "[a] new poll shows why they are more powerful-but less happy." The July/August 2012 issue of the Atlantic shows a woman from the waist down in a grey pencil skirt, stockings and heels carrying a brown leather briefcase in which a naked toddler is peeking out. The cover story questions: "Why Women Still Can't Have it All" (Slaughter). So, it appears we have made a full circle back to the 1940s and 50s in an apparent reversal of Betty Friedan's 1963 Feminine Mystique which voiced white, middle-class women's dissatisfaction with motherhood and marriage defining their personhood, and in which she advocated woman's right to find contentment elsewhere than homemaking and child-rearing. Despite the photographic message claiming the contrary, in fact, the creators of A Day in the Life of the American Woman basically tell their readers that they cannot indeed have it all.

The United States has repeatedly drawn upon images of American women in periods of difficulties in order to strengthen the national morale, embody values and send an encouraging message to Americans all around the country. This is all the truer in a culture as visual as the twenty-first century's. A Day in the Life of the American Woman falls into the continuum of visual media aiming to unite and transmit hope for the future through the adherence of American values of freedom, individualism and egalitarianism. As early twenty-first-century America focused on multiculturalism and the War on Terror, fears and insecurities that the American identity was being weakened intensified as the need for national unity increased. In 2005, with the return to conservatism that marked the beginning of the twenty-first century, the perpetuation of universality maintained an ideology that in fact upheld inequalities and reinstated traditional norms. A Day in the Life of the American Woman alleviated fears through reassuring visual discourse "proving" that the commitment to American values continues. Whether collectively or individually, the numerous women embodied the values of individualism, egalitarianism and patriotism, producing a very idealistic and universalized portrayal of the American society through the lens of the American woman. This vision reinforced Seymour Lipset's concept of American exceptionalism, where the United States is "the most religious, optimistic, patriotic, rights-oriented, and individualistic" (Lipset 26). The embodiment of these values through real stories of American women makes more tangible, the abstract notion of "Americanness" and unites people under an ideal version. As Ernest Renan points out in his famous Qu'est-ce qu'une nation, this idealism and appeal to hope and progress are essential elements of the nation (Renan 31). ${ }^{36}$ By articulating national values through universal values of humanist photojournalism, these representative citizens seem to tell "their" story as "our" story. The power of such a book lies in its classic documentary photo-essay format mixing pictures and words that construct objective "truths" in which readers derive pleasure and reassurance from recognizing not a single, mythicized American woman, rather a universalized composite American woman through "real life" daily "stories." The visual and textual discourses show the readers acceptable behavior for women across the United States to emulate. "The women we encountered in the course of this project have truly inspired us," the creators emphasized. "We hope that they will also inspire you" (Wohlmuth et al. 9). 


\section{BIBLIOGRAPHY}

\section{Primary sources}

“American Woman (The)." Life, December 24, 1956. Description available at www.originallifemagazines.com/LIFE-Magazine-December-24-1956-P2553.aspx. Accessed May 30, 2018.

"Family of Man (The)." Museum of Modern Art, January 24-May 8, 1955. www.moma.org/ calendar/exhibitions/2429?\#installation-images. Accessed May 30, 2018.

"Inequality across Gender Diversity." https://inequality.org/gender-inequality/. Accessed November 25, 2018.

SLAUGHTER, Anne-Marie. “Why Women Still Can't Have it All.” Atlantic Monthly, July/August, 2012. www.theatlantic.com/magazine/archive/2012/07/why-women-still-cant-have-it-all/ 309020/. Accessed March 31, 2019.

"State of the American Woman (The)." Time, October 26, 2009. content.time.com/time/covers/ 0,16641,20091026,00.html. Accessed May 30, 2018.

"What Is the American Look." Life, May 21, 1945, p. 87-91. Available at quitecontinental.net/ 2011/03/06/life-archives-the-american-look. Accessed March 31, 2019.

\section{Secondary Sources}

ADAMS, Bryan. American Women. New York: Power House Books, 2005.

ANDERSON, Benedict. Imagined Communities. 1983. London: Verso, 1996.

AZOULAY Ariella. The Civil Contract of Photography. Brooklyn: Zone Books, 2008.

BAHRENBURG, Genevieve, and Claiborne SWANSON FRANK. American Beauty. New York: Assouline, 2012.

BARTHES, Roland. La Chambre claire. Note sur la photographie. Paris: Gallimard, 1980.

---. Mythologies, Paris: Seuil, 1957.

BAUMGARDNER, Jennifer, and Amy RICHARDS. Manifesta: Young Women, Feminism, and the Future. 2000. New York: Farrar, Straus, and Giroux, 2010.

BROWDER, Laura, and Sasha PFLADGING. When Janey Comes Marching Home: Portraits of Women Combat Veterans. Chapel Hill: University of North Carolina Press, 2010.

BUTLER, Judith. Gender Trouble: Feminism and the Subversion of Identity. New York: Routledge, 1990. COLIN BAYLY, Heather Jane. "Presse et nationalisme: le cas de Life, 1944-1950." PhD dissertation in American studies. Université d'Angers, 2003, 2 Vols.

COOKMAN, Claude. American Photojournalism: Motivations and Meanings. Evanston: Northwestern University Press, 2009.

CURTIS, Edward S., Alan BISBORT, and Sara DAY. Heart of the Circle: Photographs of Native American Women. Petaluma: Pomegranate Publishing, 1997. 
DOUGLAS, Susan J., and Meredith W. MICHAELS. The Mommy Myth: The Idealization of Motherhood and How It Has Undermined All Women. New York: Free Press, 2004.

FALUDI, Susan. Backlash: The Undeclared War Against American Women. 1991. New York: Three Rivers Press, 2006.

FERRATO, Donna. Living With the Enemy. 1991. New York: Aperture, 2005.

FINLAY, Barbara. George W. Bush and the War on Women: Turning Back the Clock of Progress. New York: Zed Books, 2006.

FREUND, Gisèle. Photographie et société. Paris: Seuil, 1974.

GENZ, Stéphanie, and Benjamin BRABON. Postfeminism: Cultural Texts and Theories. 2009.

Edinburgh: Edinburgh University Press, 2018.

GRANT, Ted, and Sandy CARTER. Women in Medicine: A Celebration of Their Work. Buffalo: Firefly

Books, 2004

GREENFIELD, Lauren. Girl Culture. San Francisco: Chronicle Books, 2002.

HAYS, Sharon. The Cultural Contradictions of Motherhood. New Haven: Yale University Press, 1996.

HILL COLLINS, Patricia. "The Meaning of Motherhood in Black Culture and Black MotherDaughter Relationships." Gender Through the Prism of Difference. 2005. Eds. Maxine Baca ZINN, Pierrette HONDAGNEU-SOTELO, Michael A. MESSNER, and Stephanie J. NAWYN. Oxford, Oxford University Press, 2016, p. 315-324.

HOUGH, Jessica, and Catherine OPIE. Catherine Opie: 1999/In and Around Home. Ridgefield: Aldrich Contemporary Art Museum/Orange County Museum of Art, 2006.

HUNTINGTON, Samuel P. “The Hispanic Challenge.” Foreign Policy, March 1, 2004. www.foreignpolicy.com/articles/2004/03/01/the_hispanic_challenge. Accessed July 2, 2014.

KINSER, Amber E. Motherhood and Feminism. Berkeley: Seal Press, 2010.

LANKER, Brian. I Dream a World: Portraits of Black Women Who Changed America. 1989. New York: Stewart, Tabori \& Chang, 1999.

LEIBOVITZ, Annie, and Susan SONTAG. Women. New York: Random House, 2000.

LEWIS, Sarah, and Adrienne EDWARDS. Carrie Mae Weems: Kitchen Table Series. New York: Damiani/ Matsumoto Editions, 2016.

LEWIS, Vicky. Side-By-Side: Photo History of American Women in the Military. New York: Stewart, Tabori \& Chang, 1999.

LIPSET, Seymour Martin. American Exceptionalism: A Double-Edged Sword. New York: Norton, 1996.

MAUSHART, Susan. Mask of Motherhood: How Becoming a Mother Changes Everything and Why We Pretend It Doesn't. New York: New Press, 1999.

MITCHELL, W.J.T. What Do Pictures Want? Chicago: University of Chicago Press, 2005.

NEWTON, Julianne H. The Burden of Visual Truth: The Role of Photojournalism in Mediating Reality. Mahwah: Lawrence Erlbaum Associates, 2001.

NOCHLIN, Linda. “Why Have There Been No Great Women Artists?” 1971. Nochlin, Linda (1988). Women, Art and Power \& Other Essays. New York: Routledge, 2018, p. 145-176. Available at www.writing.upenn.edu/library/Nochlin-Linda_Why-Have-There-Been-No-Great-WomenArtists.pdf. Accessed November 25, 2018. 
ORVELL, Miles. American Photography. Oxford: Oxford University Press, 2003.

POIVERT, Michel. “La photographie est-elle une 'image'?” Études photographiques, no. 34, 2016, journals.openedition.org/etudesphotographiques/3594. Accessed November 25, 2018.

PINNEY, Melissa Ann, and Ann PATCHET. Regarding Emma: Photographs of American Women and Girls. Chicago: University Chicago Press, 2003.

RENAN, Ernest. Qu'est-ce qu'une nation. 1887. Paris: Mille et une nuits, 1997.

RECKITT, Helena, and Peggy PHELAN. Art and Feminism. 2001. New York: Phaidon, 2012.

RITCHIN, Fred. Bending the Frame: Photojournalism, Documentary and the Citizen. New York: Aperture, 2013.

RUGG, Linda Haverty. Picturing Ourselves: Photography and Autobiography. Chicago: University of Chicago Press, 1997.

SAWADA, Nao. "Sartre et la photographie: autour de la théorie de l'imaginaire." Etudes française, vol. 49, no. 2, 2013, www.erudit.org/en/journals/etudfr/2013-v49-n2-etudfr0903/1019494ar. Accessed November 26, 2018.

SCHNEIDER, Rebecca. Explicit Body in Performance. New York: Routledge, 1997.

SIMMONS, Laurie. The Love Doll. New York: Salon 94/Tomio Koyama Gallery, 2012.

SMITH, Anthony D. National Identity. London: Penguin, 1991.

---. Myth and Memories of the Nation. Oxford: Oxford University Press, 1999.

SONTAG, Susan. On Photography. New York: Penguin Books, 1971.

SOUTTER, Lucy. "Enigmatic Spectacle: Key Strategies in Contemporary Staged Photography." Role Models: Feminine Identity in Contemporary American Photography. Eds. Susan Fisher STERLING and Kathryn WAT. London: Scala, 2008, p. 11-21.

WAINWRIGHT, Loudon. The Great American Magazine: An Inside History of Life. New York: Knopf, 1986.

WOHLMUTH, Sharon J., Carol SALINE, and Dawn SHEGGEBY. A Day in the Life of the American Woman: How We See Ourselves. New York: EpiCom Media, 2005.

\section{NOTES}

1. Throughout this article, "traditional" refers to the mid-twentieth century stereotypical vision of the American woman as a stay-at-home mom who devotes her time to raising two or three children and a wife whose husband is the breadwinner.

2. Adams claims his book is "a tribute to the beauty, strength and character of American women." Frank claims to illustrate "a survey of quintessentially American women." In her promotional video, she insists her photos of these American women resonate their inner soul, heritage and landscape.

3. Rebecca Schneider defines feminism as an "embattled term to mean work with an agenda to provoke recognition of the historical, cultural, social, and political situation of those marked "woman"' (Schneider 10).

4. Smith (1991) provides a good starting point on how ethnic origins, religion, language and shared symbols can provide a sense of national identity. 
5. Among the 56 photographers, at least 19 had earned prominent awards: three had been Pulitzer prize finalists, three were awarded Pulitzer prizes for Feature Photography, another three had obtained the Pulitzer prize for Breaking News Photography and one was awarded a Pulitzer prize for Explanatory Journalism. Many others had received awards from the National Press Photographer's Association or had been named photographer of the Year by the same association. Four more had won the World Press photo award.

6. This tradition dates back to the beginning of the twentieth century when amateurs recorded leisure scenes from around the home, featuring subjects relaxed and in their natural state of being, formal parties and celebrations, where subjects may be lined up for a group photograph, family adventures, tourist pictures [...]. The making of such self-images "confirmed a certain average existence, and sometime an ideal family life [...]" (Orvell 144).

7. The press began integrating photographs (and even engravings of photographs) as early as technologically possible and illustrated journalism flourished at the beginning of the twentieth century. As early as 1914, the New York Times began experimenting with a mix of text and photographs in the supplement Mid-Week Pictorial. Picture magazines were introduced in America in the thirties following the European tradition already established since the twenties in Germany (Muncher Illustrierte, Berliner Illustrrierte Zeitang), England (Illustrated London News, Weekly Illustrated) and France ( $\mathrm{Vu}$, Pour Vous). In 1936, Life magazine was the first to conceive photographs beyond the role of simple illustrations; they functioned as the principal component to news stories. Other picture magazines soon followed such as Look (1937).

8. Photobooks became popular starting in the 1930 s with publications by famous photojournalists, writers and/or photographers such as Erskine Caldwell and Margaret BourkeWhite, You Have Seen Their Faces (1937) and Say, Is This the U.S.A. (1941); James Agee and Walker Evans, Let Us Now Praise Famous Men (1941); Walker Evans, American Photographs (1962). They provided a mix of text and images; a sequencing of images in order to create a narrative of the photos with their relationship to what came previously and what was to develop after (Orvell 113).

9. Back in the heyday of the picture magazine a photo-essay layout for one story could occupy up to 9 pages with almost two-dozen pictures. Today in America, magazine editors are no longer interested in photo stories and the trend among the major (remaining) newsmagazines, Time and Newsweek, has been to return to a policy focusing on the primacy of the text. Important stories may include up to four photographs, but more often news stories are accompanied by one visually powerful, symbolic photograph that sums up the event. The long-format photo-essay is rarely used.

10. In reality, the "objective photojournalist" has not existed since the first documentary photographer, Jacob Riis, who positioned himself with social superiority in relation to his subjects and evinced disdain for them (Orvell 130). From Riis to the photographers of the FSA (Farm Security Administration which is known for its photographs of America during the Great Depression), "directing" the subjects of the photo-essay in order to get the "truthful" image was justified in order to represent the general truth of social conditions of the time (Orvell 115). In 1948, Gene Smith's renowned photo-essay, "The Country Doctor" was the harbinger of a new age in photojournalism. "In a new approach to magazine photojournalism, Smith wanted his pictures to emerge from carefully observing the subject while remaining unobtrusive. He rejected the old practice-implicit in the shooting script-of controlling the subjects in order to construct pictures based on editors' preconceived ideas" (Cookman 165). Without acknowledgment from the photographers, it is impossible to know whether or not a photo-essay in the Day in the Life was directed in order to obtain the "truthful" images.

11. "She keeps young in spirit and appearance well past the age when other women would consider themselves middle-aged [...]" ("What Is the American Look" 90). 
12. "Granny Heart," Jamilah Peters Muhammad (14-15); "Fighting Chance," Whitney Drayton (42-43); "Moved by the Spirit," Sister Kaye Stramler (68-71); "Off the Streets," Lorena Macias (122); "Soul Sisters," Ann Harris and Sylvia Scott (126-129); "Diva Mom," Denyce Graves (132-133); "Facing East," Janiece Hameed (141).

13. "Classical Beauties," Lucia, Maria, and Angella Ahn (94-97); "Major Courage," Major Tammy Duckworth (134-137); “The Art of Living," Ruth Duckworth (164-169).

14. "Border Patrol," Adela Vazquez (22-25); "New Sheriff in Town," Lupe Valdez (76-79); “Tomale Tia," Irma De Los Santos (149).

15. "The Shape of Success," Sara Blakely (18-21); "A Home of Her Own," Karen Owens (93).

16. "A Healing Heart," Anne Rosenberg (86-91).

17. "Circle of Friends," Sue, Claire, Jane, Bea, Ann, Nancy (28-29); "Love Goes On," Maureen Fanning (106-109).

18. "Live Wire," Dee Von Entress (92); "Family Practice," Michelle Drury and Marcie Lavigne (124-125).

19. "Hog Heaven," Julie Gauman (148).

20. "Built for Speed," Leilani Münter (102-105).

21. "Live Wire," Dee von Entress (92).

22. "New Sheriff in Town," Lupe Valdez (76-79).

23. "A Home of Her Own," Karen Owens (93).

24. "Border Patrol," Adela Vazquez (22-25); "Military Engagement," Lieutenant Jo-Ann Feigofsky (62-65); "In the Green Zone," Private First Class Jennifer Lipzer (110-111); “Major Courage," Major Tammy Duckworth (134-137).

25. Along with the anti-feminist "backlash" of the 1980 s and 90 s, during the twenty-first century and George W. Bush's administration another strand of post-feminism emerged: "New Traditionalism." According to Genz and Brabon, New Traditionalism, "articulates a vision of the home as women's sanctuary from the stress of their working lives [...]. The domestic sphere is rebranded as a domain of female autonomy and independence" (51-52). Allied with the religious right, George W. Bush appealed to the "pro-family" political spectrum and whittled away at abortion rights and family planning programs. Women activists joined conservative organizations such as Concerned Women of America which was formed in opposition to the National Organization for Women (NOW) or the Independent Women's Forum to advocate for more traditional gender roles. New Traditionalism extended beyond the political scene into popular culture with the airing of shows such as the highly popular televised series Desperate Housewives which depicts the desperation of suburban housewives trying to have it all.

26. Included in many books on feminist art and photography, Donna Ferrato is a renowned photojournalist who has spent decades documenting domestic violence and advocating for battered women. Her seminal work, Living With the Enemy, (1991) has helped change how abuse is viewed and dealt with in American society.

27. "All About Mee," (52-55).

28. "Classical Beauties," (94-97).

29. "Major Courage," (134-137).

30. 1920s Soviet filmmaker Lev Kuleshov is reputed for having filmed an actor with a neutral expression on his face succeeded by other unrelated images such as a bowl of soup. Asked what the actor's emotion was, the audience assumed he was interacting with the objects inter-cut with himself and interpreted his neutral face expression as hunger, for example. This juxtaposition of two images tends to result in the viewer unconsciously assuming a spatial relationship between one shot and the next.

31. 41 photographs out of 258 (16\%) include men who are clearly positioned as husband, father, colleague and coach. 
32. Inequality.org provides a presentation of current gender inequalities in the United States based upon statistics taken from the Department of Labor, the Institute for Women's Policy Research and the Census Bureau among others ("Inequality across Gender Diversity").

33. On May 17, 2004, Massachusetts became the first state in the United States to legalize samesex marriage.

34. Inspired by the social awakenings of the Civil Rights movement and the anti-war movement, a feminist art movement emerged in the sixties and seventies protesting the lack of inclusion of women artists. In 1971, Linda Nochlin's influential essay, "Why Have There Been No Great Women Artists?" marks the beginning of feminist inquiry into art history. Five years later, in collaboration with Ann Sutherland Harris, they curated an exhibit "Woman Artists 1550-1950" that traveled around the United States. In addition to these initial efforts of lending legitimacy to the work of neglected women artists, a group of anonymous women hiding their identity behind gorilla masks, began their combat against sexism in the art world (Reckitt 21, 35). Starting in 1985, the Guerrilla Girls, as they called themselves, used humor and parody in their posters, billboards, publications and other actions in order to expose the bias against women in the visual arts.

35. Baumgardner and Richards' research confirmed that the editorial departments of major magazines were predominately male. They checked their statistics 10 years later to discover little progress had been made in gender parity and the situation was even worse for the Internet (Baumgardner and Richards 100-101).

36. "La nation, comme l'individu, est l'aboutissement d'un long passé d'efforts, de sacrifices et de dévouements [...]. Avoir des gloires communes dans le passé, une volonté commune dans le présent ; avoir fait de grandes choses ensemble, vouloir en faire encore, voilà les conditions essentielles pour être un peuple."

\section{ABSTRACTS}

In 2005, fifty women photographers participated in a project to capture the everyday lives of over seventy American women on the same day in order to provide a composite portrait of the modern American woman in the twenty-first century. Through a close analysis of the photographs and accompanying texts this article questions to what extent the definition proposed by the book A Day in the Life of the American Woman remains faithful to a "traditional" vision of the American woman, or on the contrary to what extent this definition reflects an empowered and diversified vision of women since the 70 s feminist movement. Our findings reveal that although A Day in the Life presents a diversified vision of the modern, American woman, it simultaneously remains faithful to a more stereotypical vision where a woman's primary goal is to remain a mom.

Au cours d'une même journée, en 2005 cinquante femmes photographes ont participé à un projet visant à saisir sur pellicule la vie quotidienne de plus de soixante-dix Américaines afin de constituer un portrait composite de la femme américaine moderne du XXI ${ }^{\mathrm{e}}$ siècle. Cet article se propose de faire une lecture approfondie des photographies et des textes du livre ainsi produit, $A$ Day in the Life of the American Woman, afin d'évaluer dans quelle mesure cette vision proposée de la femme américaine reste traditionnelle ou, au contraire, dans quelle mesure cette dernière est remise en question, le mouvement féministe des années 1970 ayant permis l'émergence d'une 
image diversifiée et émancipée. Nos résultats révèlent que, même si A Day in the Life présente une vision diversifiée de la femme américaine moderne, elle reste en même temps fidèle à une vision stéréotypée dans laquelle le premier objectif d'une femme serait de rester mère.

\section{INDEX}

Keywords: photo-essay, American woman, identity, momism, photojournalism, humanist photography, individualism, self-made man, diversification of American society, imagined community

Mots-clés: essai photographique, femme américaine, identité, idéologie de la maternité, photojournalisme, photographie humaniste, individualisme, self-made man, diversification de la société américaine, imaginaire national

\section{AUTHOR}

\section{JANE BAYLY}

Université de Nantes, CRINI 